\title{
Modeling of Hybrid Solar Palel For Producing Hydrogen
}

\author{
Chawki AMEUR MENAD ${ }^{1, *}$, and Rabah GOMRI ${ }^{1}$ \\ ${ }^{1}$ University Frères Mentouri Constantine, Faculty of Sciences and Technology, Department of Génie \\ Climatique, 25000 Constatine, Algeria
}

\begin{abstract}
Applied renewable energy for improving the quality of life has taken the major part of the modern research. The purpose of doing this research is developing new technology which is modeling a new hybrid solar panels generating by different sources of renewable energy, and mini mechanical systems. As a result generating hybrid solar panel by geothermal energy and solar energy, including the mini-turbine increases the water's temperature from $95^{\circ} \mathrm{C}$ to $622^{\circ} \mathrm{C}$ for producing the hydrogen through the electrochemical thermodynamic by using HTES Technology.
\end{abstract}

\section{INTRODUCTION}

A lot of research projects have been developed about exploiting the energy in different ways. However; the renewable sources became the most important field of research due to the availability and impact on the environment. Few examples about using solar systems for hydrogen were proposed. Acakpovi et al [1] have studied modeling solar power generation by photovoltaic cell, where the modeling was under Simulink, the obtained results confirmed some novelty comparing to the previous research. Another research have published about design and studying new technique called Support Vector Machine (SVM) based on experimental experience. Where Kazem et al [2], obtained results proofed that the studied model achieved less MSE in comparing to the previous research about management energy generation. Moreover, Salmi et al [3] have developed a new model photovoltaic cell by using Matlab/SIMULINK. The model is based on mathematical equations and described through an equivalent circuit including a photocurrent source. In addition, an experimental test bench was built and the obtained results exhibited a good agreement with the simulation ones. Regarding studying novel modeling technique of PV module with a fuzzy logic based MPPT algorithm and boost converter in Simulink environment which was developed by Mahamudul et al [4]. The main result has given an important contribution which is simplification of PV modeling technique and implementation of fuzzy based MPPT system to track maximum power efficiently. Other research about developing methodology for production of hydrogen by electrolysis system was proposed by Ayati et al [5] where the electricity is delivered by photovoltaic panel. Wilson et al [6] have mentioned in their research the objective of generating Hydrogen by solar photovoltaic (PV) array and

${ }^{*}$ Corresponding author: c.ameurmenad@gmail.com 
then collected for data analysis to demonstrate efficiency of the hydrogen production in all the steps of the experiment. Their positive results proofed that the studied case model allows demonstrating at least one hour operation per hydrogen charging at room temperature. Agrafiotis et al [7] have been proposed the exploitation of solar energy for the dissociation of water and production of hydrogen via an integrated thermo-chemical reactor/receiver system. They obtained results which have explained that the operation of the complete cycle by a single solar energy converter. Some researchers were focusing just in production of hydrogen by electrolysis powered from wind and solar sources. As a result they got the reasonable price for producing hydrogen from wind and solar energy [8]. Other choice for exploiting solar power for creating new opportunities for hydrogen production, where the final cost estimation for hydrogen and solar electricity generation will show the potential of both technologies for a sustainable energy industry, this research has been developed by Volker Quaschning and Franz Trieb [9]. Finally, Crook et al [10] have developed a new simulation method for creation a hybrid panels by combination between solar thermal energy and photovoltaic energy and phase change material system; they considered the application of wind energy for production of electricity.

\section{DESCRIPTION OF THE HYBRID SOLAR PANEL}

The proposed hybrid solar panel is based on combining between three different sources of energy, which are Silicon solar cells, mini-turbine and geothermal source of energy. The panel absorbs the solar radiation and transforms it to electricity through solar cells. Moreover the geothermal source passes through channel which is rounding by electrical resistance for increasing the vapor water temperature for hydrogen production by using the electrochemical thermodynamic by using HTES Technology. And the last part, which is the mini-turbine for increasing the amount of electricity producing by hybrid solar panel. The studied case consists modeling two different parts; the first one is thermal part which combines between geothermal energy and mini-mechanical system (mini-turbine). The second part consists modeling photovoltaic cells. Coupling between the two parts gives us the total power produced by the hybrid solar panel. The aim of studying the proposed case with mini turbine is to gain more amount of electricity and increasing of the temperature of vapor water for production of electricity and hydrogen.

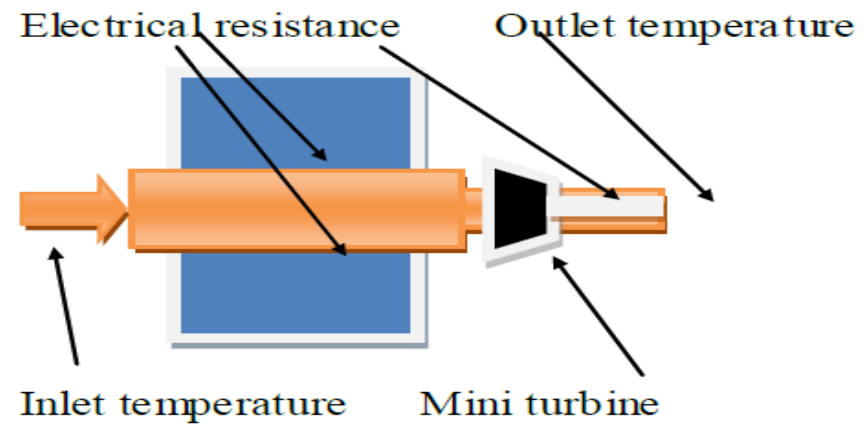

Fig. 1. Coupling between the photovoltaic energy and geothermal energy for production of electricity with mini turbine and increasing of vapor water. 


\section{MODELING OF THE HYDRIDE SOLAR PANEL}

\subsection{Electrical part}

In this part; understanding the Ideal Solar Cell (simplified), is the aim for getting the maximum Power producing. The voltage current characteristics equation of PV Ideal solar cell simplified is given by:

$$
\mathrm{I}=\operatorname{Iph}-I_{0} \cdot\left(\exp \left(\frac{q \cdot v}{n \cdot k \cdot T}\right)\right)
$$

Where the photon current in solar Ideal cell is:

$\mathrm{Iph}=(I S+K i(T-T n)) \frac{G}{G n}$

Where $K i=0.0017 \mathrm{~A} /{ }^{\circ} \mathrm{C}$ is the cell's short circuit current temperature coefficient and $G$ is the solar radiation $(\mathrm{W} / \mathrm{m} 2)$.

The cell's saturation current varies with temperature which is:

$$
\operatorname{Is}(\mathrm{t})=I s \cdot\left(\frac{t}{t n}\right)^{3} \cdot \exp \left(\frac{E g}{V t}\left(\frac{t}{t n}-1\right)\right)
$$

Where $I s$ is the diode reverse saturation current, $t n$ is the nominal temperature, $E g$ is the band gap energy of the semiconductor and $V t$ is the thermal voltage.

$\mathrm{Vt}$ is called thermal voltage:

$$
V t=\frac{k \cdot T}{q}=\frac{T}{11600}
$$

The current output of PV module is:

$$
I=N p \cdot I p-N p I 0\left(\exp \left(\frac{q \cdot v}{n \cdot k \cdot T}\right)\right)
$$

\subsection{The thermal part}

The electrical power produced by the mini turbine is shown in the following equation:

$\mathrm{Pu}=0,97.9,81 . \mathrm{nt} \cdot \mathrm{ng} \cdot \mathrm{Qt} . \mathrm{Hn}$

Where; Pu, Qt, Hn, nt, ng represent respectively the amount of energy produced (W), the flow of the mini turbine $(\mathrm{m} 3 / \mathrm{s})$, net drop $(\mathrm{m})$, the efficiency of the mini turbine, efficiency of the generator (generator of the mini turbine). The following equation show the net drop :

$$
\mathrm{Hn}=\mathrm{Hb}-\mathrm{HL}-\mathrm{V}^{2} / 2 . \mathrm{g}
$$

Where, Hb, HL, v, g, represent respectively Gross drop, higher, celerity, cceleration (HL represent about $10 \%$ To $15 \%$ of $\mathrm{Hb}$ ). The outlet temperature is depicts in the following equation:

$$
\mathrm{Ts}=\mathrm{Te}+(\mathrm{Pu} / \mathrm{m} . \mathrm{Cp})
$$


Where Ts, Te, m, Cp, Pu: are respectively outlet temperature, inlet temperature, specific heat, electrical power of vapor water between the inlet and outlet point of each channel connected on the solar panel.

\subsection{Programming the hybrid solar panel by using FORTRAN 95}

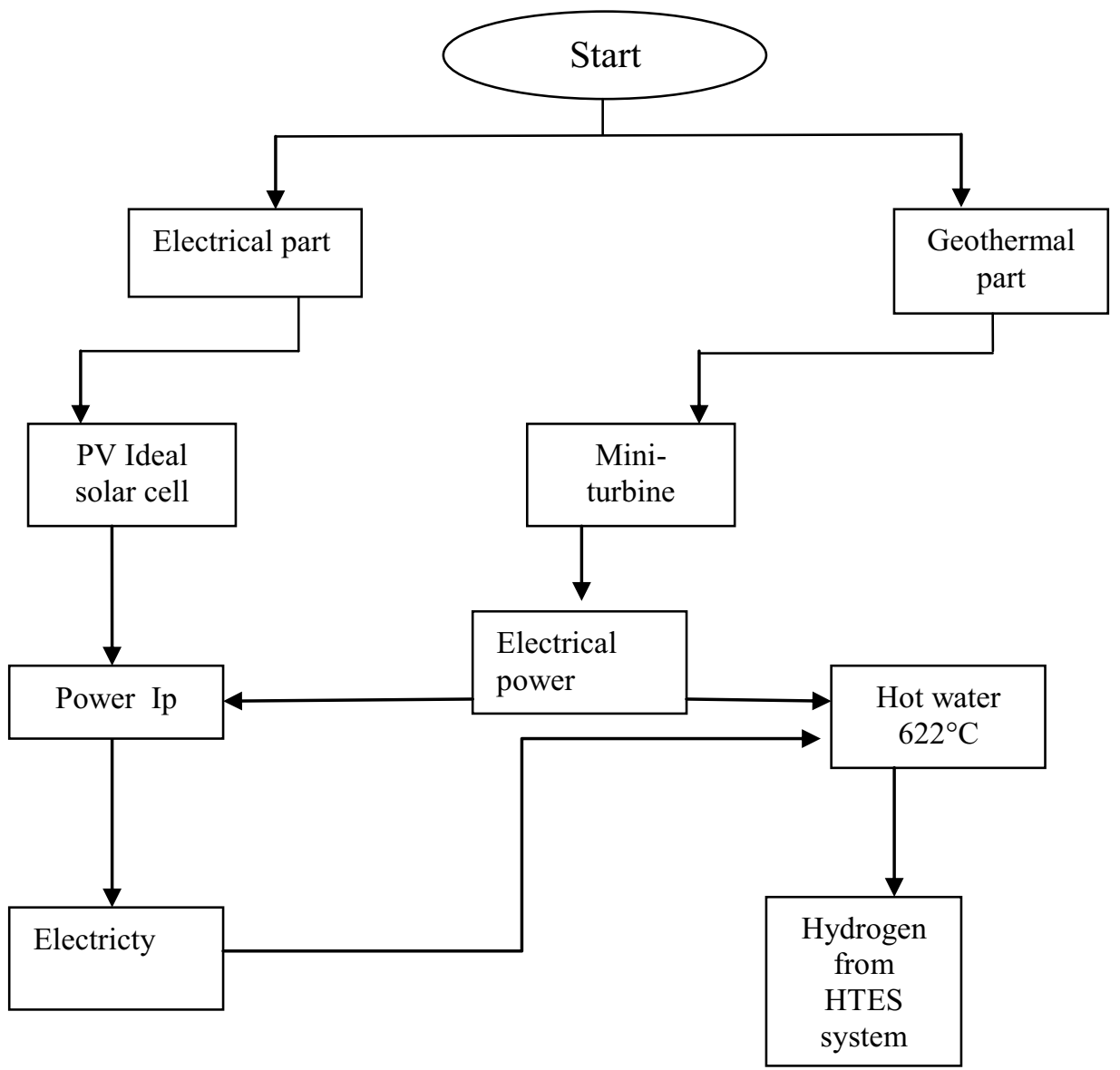

Fig.2. programming FOTRAN 95 for Hydride solar panel for hydrogen production

\section{Hydrogen production}

\subsection{Description of hydrogen production from HTES system}

Production of hydrogen from steam water at $622^{\circ} \mathrm{C}$ in the studied case is possible by using the HTES technology where the temperature varied between $600^{\circ} \mathrm{C}$ and $1000^{\circ} \mathrm{C}$. However there is another possibility to increase the temperature until 1000 from the same hybrid solar panel, and start producing hydrogen from different such as:

$\mathrm{H}_{2} \mathrm{SO}_{4}\left(130^{\circ} \mathrm{C}\right.$ to $\left.1000^{\circ} \mathrm{C}\right)$.

$$
\mathrm{SO}_{2}+\mathrm{I}_{2}+2 \mathrm{H}_{2} \mathrm{O} \rightarrow \mathrm{H}_{2} \mathrm{SO}_{4}+2 \mathrm{HI} \quad\left(100^{\circ} \mathrm{C}-130^{\circ} \mathrm{C}\right)
$$




$$
\begin{array}{ll}
\mathrm{H}_{2} \mathrm{SO}_{4} \rightarrow \mathrm{SO}_{2}+\mathrm{H}_{2} \mathrm{O}+1 / 2 \mathrm{O}_{2} & \left(800^{\circ} \mathrm{C}-1000^{\circ} \mathrm{C}\right) \\
2 \mathrm{HI} \rightarrow \mathrm{H}_{2}+\mathrm{I}_{2} & \left(300^{\circ} \mathrm{C}-400^{\circ} \mathrm{C}\right)
\end{array}
$$

$\mathrm{CH}_{4}\left(700^{\circ} \mathrm{C}-1000^{\circ} \mathrm{C}\right)(2 \mathrm{Bar}-25 \mathrm{Bar})$

$$
\begin{aligned}
& \mathrm{CH}_{4}+\mathrm{H}_{2} \mathrm{O} \leftrightarrows \mathrm{CO}+3 \mathrm{H}_{2} \\
& \mathrm{CO}+\mathrm{H}_{2} \mathrm{O} \leftrightarrows \mathrm{CO} 2+\mathrm{H}_{2}
\end{aligned}
$$

\section{RESULTS AND DISCUSSIONS}

The aim of the proposed model is just develop a hybrid solar panel for one goal which is producing hydrogen by using HTES technology, so the water vapor water should be varied between $600^{\circ} \mathrm{C}$ to $1000^{\circ} \mathrm{C}$, the following table resume the purpose of the research.

Table1. characteristics of hydride solar panel for hydrogen production.

\begin{tabular}{|l|c|c|c|c|}
\hline & $\begin{array}{c}\text { Power } \\
(\mathrm{W})\end{array}$ & $\begin{array}{c}\text { Outlet Temperature } \\
\left({ }^{\circ} \mathrm{C}\right)\end{array}$ & $\begin{array}{c}\text { Number of panels } \\
\text { obtained }\end{array}$ & $\begin{array}{c}\text { Mini-turbine } \\
(\mathrm{W})\end{array}$ \\
\hline Hybrid solar panel & 1784 & 622 & 4 & 3000 \\
\hline
\end{tabular}

The obtained results resumes the studied model which has given an electrical power of $1784 \mathrm{~W}$ in 4 solar panel were connected in serial, however the most important factor is the high temperature of the vapor water for hydrogen production. Moreover; the power obtained by mini-turbine has increased the total amount of electricity, for focusing in one purpose which is hydrogen production.

In terms the variation of outlet temperature through the four hybrid solar panels; the following table (Table. 2) explains that the power obtained increases the temperature of the vapor water by transforming electrical energy to thermal energy through an electrical resistance around the channel. Increasing the power from $500 \mathrm{~W}$ to $1784 \mathrm{~W}$ has increased the temperature from $310^{\circ} \mathrm{C}$ to $622^{\circ} \mathrm{C}$. As a result the proposal model is stable for producing electricity and instable for increasing the vapor water temperature. However; it achieves the exact temperature for producing hydrogen by using HTES system

Table 2. Variation of outlet temperature on function of Power produced by hybrid panel.

\begin{tabular}{|c|c|}
\hline $\mathrm{Pu}(\mathrm{W})$ & $\mathrm{Ts}\left({ }^{\circ} \mathrm{C}\right)$ \\
\hline 500 & 310 \\
\hline 1000 & 425 \\
\hline 1500 & 545 \\
\hline 1784 & 622 \\
\hline
\end{tabular}

Finally; understanding the variation of speed of the vapor water is necessary for calculating the power produced by the mini-turbine. The Table 3 mentions that increasing the speed of vapor water improves the quality of the hybrid solar panel by increasing the power 
producing. In addition; increasing the speed from $5.10 \mathrm{~m} / \mathrm{s}$ to $16 \mathrm{~m} / \mathrm{s}$ has increased the produced power from $500 \mathrm{~W}$ to $1784 \mathrm{~W}$ so a difference of $1400 \mathrm{~W}$.

Table 3. variation of vapor speed on function of Power produced by hybrid panel..

\begin{tabular}{|c|c|}
\hline $\mathrm{Pu}(\mathrm{W})$ & $\mathrm{V}(\mathrm{m} / \mathrm{s})$ \\
\hline 500 & 5.10 \\
\hline 1000 & 7.10 \\
\hline 1500 & 10.10 \\
\hline 1784 & 16 \\
\hline
\end{tabular}

\section{Results of Hydrogen production}

The obtained results show that the proposed hybrid solar panel is able to produce a considerable amount $\mathrm{H} 2$, However; $\mathrm{CH} 4$ cycle is the best cycle in high HTES systems.

Table 4. Amount of hydrogen produced from $\mathrm{H} 2 \mathrm{SO} 4$ and $\mathrm{CH} 4$.

\begin{tabular}{|c|c|c|}
\hline $\begin{array}{l}\text { Cycles for Hydrogen } \\
\text { Production. }\end{array}$ & $\begin{array}{c}\text { Hydrogen productivity. } \\
\mathrm{MJ} / \mathrm{KgH}_{2}\end{array}$ & $\begin{array}{l}\text { Amount of } \\
\text { Hydrogen } \\
\text { production. }\end{array}$ \\
\hline $\begin{array}{l}\text { H2SO4. } \\
\qquad \begin{array}{l}\mathrm{SO}_{2}+\mathrm{I}_{2}+2 \mathrm{H}_{2} \mathrm{O} \rightarrow \mathrm{H}_{2} \mathrm{SO}_{4}+2 \mathrm{HI} \\
\mathrm{H}_{2} \mathrm{SO}_{4} \rightarrow \mathrm{SO}_{2}+\mathrm{H}_{2} \mathrm{O}+1 / 2 \mathrm{O}_{2} \\
2 \mathrm{H} \rightarrow \quad \mathrm{H}_{2}+\mathrm{I}_{2} \\
\end{array}\end{array}$ & $295,500 \mathrm{MJ} / \mathrm{KgH} 2$ & $0,517 \mathrm{KgH} 2 /$ day \\
\hline $\begin{array}{ll}\mathrm{CH} 4 & \\
& \mathrm{CH} 4+\mathrm{H} 2 \mathrm{O} \leftrightarrows \mathrm{CO}+3 \mathrm{H} 2 \\
& \mathrm{CO}+\mathrm{H} 2 \mathrm{O} \leftrightarrows \mathrm{CO} 2+\mathrm{H} 2\end{array}$ & $165 \mathrm{MJ} / \mathrm{KgH} 2$ & $0,9394 \mathrm{KgH} 2 /$ day \\
\hline
\end{tabular}

\section{References}

1. A. Acakpovi, E. Ben Hagan; Novel Photovoltaic Module Modeling using Matlab/Simulink, International Journal of Computer Applications (0975 - 8887) Volume 83 - No.16, (2013)

2. H.A. Kazem, J. H. Yousif, M.T. Chaichan, Modelling of Daily Solar Energy System Prediction using Support Vector Machine for Oman, International Journal of Applied Engineering Research ISSN 0973-4562 Vol. 11, Number 20, 10166-10172, (2016).

3. T. Salmi, M. Bouzguenda, A. Gastli, A. Masmoudi, MATLAB/Simulink Based Modelling of Solar Photovoltaic Cell, International Journal of Renewable Energy Research, Vol.2, No.2, (2012).

4. H. Mahamudul, M. Saad, M. I. Henk, Photovoltaic System Modeling with Fuzzy Logic Based Maximum Power Point Tracking Algorithm, International Journal of Photoenergy http://dx.doi.org/10.1155/2013/762946, (2013)

5. F. Ayati, A. M'Raoui, M. Belhamel, A. Rebai; Modélisation d'un Système de Production d'Hydrogène Solaire par Electrolyse, Rev. Energ. Ren. Vol. 7, 135-150, (2004). 
6. J.F. Wilson , S.S. Srinivasan, B. M. Moore, L. Henderson, S. Ely, P.C. Sharma; Hydrogen production using solar energy, Journal of Undergraduate Research in Physics, (2013).

7. A. Agrafiotis, M. Roeb, A.G. Konstandopoulos, L. Nalbandian, V.T. Zaspalis, C. Sattler, P. Stobbe, A.M. Steele, Solar water splitting for hydrogen production with monolithic reactors. Solar Energy, Vol. 79, 409-421, (2005).

8. A. Rahil, R. Gammon, Dispatchable Hydrogen Production at the Forecourt for Electricity Demand Shaping Sustainability, Vol.9, 1785, (2017)

9. Quaschning, F. Trieb, Solar Thermal Power Plants for Hydrogen Production, Hypothesis IV Symposium Stralsund, Germany 9-14 September, 198-202, (2001).

10. C.S. Malvi, D.W. Dixon-Hardy, R. Crook, Energy balance model of combined photovoltaic solar-thermal system incorporating phase change material, Solar Energy, Vol. 85, Issue 7, 1440-1446, (2011). 